\title{
PERUBAHAN SISTEM SPASIAL RUMAH TINGGAL BERFUNGSI GANDA DI DAERAH UMBULHARJO YOGYAKARTA
}

\author{
Hartiningsih* \\ Program Studi Desain Interior, Fakultas Seni Rupa, Institut Seni Indonesia Yogyakarta
}

A large number of college students coming from numerous cities in Indonesia has encouraged citizens of Umbulharjo, an area in the city of Yogyakarta, to use a part of their houses available for the students to rent (thereby called double-function houses). This phenomenon is very important and has inspired this research on the change of spatial system among double-function houses in Umbulharjo. The approach used in this research is "Qualitative-deductive Phenomenology" \{Modified from Ihalauw (1985), Muhajir (1992), and Sudaryono (2004)\}. The population was all double-function houses in Umbulharjo, Yogyakarta. From the observations It is obvious that there are three basic types of double-function houses, i.e. house functions as a dorm, house functions as afood-selling vendor (' warung'/small restaurant) and house functions as a shop. Based on the analysis of the change of spatial system it was found that there are differences between the change pattern and shape of houses function as a dorm and houses function as a 'warung'/restaurant and a shop. However, the changing process and motivation behind it was similar. The main motivation was social and economic.

\section{Key words: Spatial system, the change pattern and shape, social and economic motivation.}

Rumah tinggal merupakan tempat dimana kehidupan keluarga dimulai, tempat membesarkan dan mendidik anak-anak, tempat bermasyarakat, tetapi sekaligus juga tempat dimana hak privasi dihargai. Rumah yang dibangun akan selalu terjadi proses penyesuaian yang dilandasi kebutuhan penghuni untuk merasakan kenyamanan dalam kehidupannya. Perubahan dan perkembangan pada tiap bangunan rumah tinggal dapat berbeda, tergantung pada tingkat kebutuhan penghuninya dan faktor dari luar yang mempengaruhi penghuninya. Lajunya pertumbuhan kampus-kampus perguruan tinggi di daerah Umbulharjo Yogyakarta, telah menumbuhkan dan menciptakan dinamika kehidupan masyarakat sekitar lingkungan yang masih kental dengan budaya tradisionalnya. Saat ini kampus perguruan tinggi yang telah dibangun di daerah Umbulharjo sekitar 17 kampus, dengan jumlah mahasiswa sekitar 21427 orang yang terdiri dari berbagai daerah di Indonesia (Data Monografi Kecamatan Umbulharjo semester 2003). Hal ini mengakibatkan adanya penetrasi kegiatan baru ke dalam daerah tersebut. .

Maraknya renovasi rumah lama dan pembangunan rumah baru untuk usaha di daerah Umbulharjo, melahirkan daya kreasi, dan strategi yang beragam. Daya kreasi dan strategi sangat menarik untuk diketahui keterkaitannya. Serta yang dapat dilihat secara langsung dan berhubungan dengan

*Korespondensi penulis dialamatkan ke Program Studi Desain Interior, Fakultas Seni Rupa, Institut Seni Indonesia Yogyakarta, Telp/Fax: +62 274417219 
LINTAS

$\underset{\text { ISSN } 1978-0702}{\text { RU }}$

permasalahan yang timbul akibat berubahnya bentuk dan fungsi ruang di dalam rumah tinggal berfungsi ganda adalah sistem spasial. Penggunaan ruang untuk usaha, secara jelas menunjukkan bahwa rumah tidak hanya berfungsi untuk tempat tinggal saja tetapi juga untuk tempat usaha, kemungkinan dapat mengurangi privasi pemilik rumah. Begitu juga dengan beralihnya fungsi ruang, kemungkinan akan mengakibatkan berkurangnya ruang untuk kehidupan.

Fenomena di atas mengantar pada perlunya studi perubahan sistem spasial rumah tinggal berfungsi ganda dan lingkungannya, serta keterkaitan antara aspek-aspek yang melatar belakanginya.

Sistem spasial dapat digambarkan sebagai keterkaitan antara man, space dan time. Manusia selalu dihubungkan dengan ruang dan waktu, sehingga dalam aplikasi penggunaannya dapat dikategorikan dalam 2 faktor yaitu: struktur spasial, dan nilai spasial. Marti,Jr. (1997) menyatakan bahwa Struktur spasial yang berkaitan dengan fisik ruang adalah: organisasi ruang, hirarki ruang, orientasi ruang, akses/sirkulasi dan teritori fisik (elemen pembentuk ruang: dinding, lantai plafon). Sedangkan Nilai spasial berhubungan dengan makna spasial yang tentunya berkaitan dengan pemanfaatan ruang dan berhubungan dengan dimensi ekonomi, hubungan antar penghuni, sistem kultural (termasuk hubungan laki-laki dan perempuan) dan ekologi (Fauzi, 1977).

Istilah Perubahan, menurut Papageorgiou,A (1971, h.4) yang dimaksud adalah kejadian dalam suatu kontek baik yang disengaja atau tidak menjadi berbeda dari awalnya, karena pengaruh atau tindakan dari luar atau dari dirinya sendiri. Sedangkan perubahan yang dimaksud dalam penelitian ini adalah perubahan dari rumah tinggal menjadi rumah tinggal berfungsi ganda.

Silas,J.dkk (2000, h. 51) menyatakan bahwa kenyataannya sejak dahulu konsep rumah mengandung sekaligus tiga fungsi pokok yaitu: tempat berlindung; tempat membina keluarga; dan mengusahakan kesejahteraan penghuninya. Maka rumah produktif atau lebih konkritnya Rumah Berfungsi Ganda adalah rumah tinggal yang sebagian rumahnya digunakan untuk usaha (produktif) atau kegiatan ekonomi.

Penelitian ini bertujuan untuk mendapatkan konsep tentang bentuk, pola dan proses perubahan sistem spasial rumah berfungsi ganda baik dari segi arsitektur maupun interiornya. Serta dalam kaitannya dengan latar belakang mengusahakan jasa layanan mahasiswa di daerah Umbulharjo Yogyakarta.

Fenomena perubahan sistem spasial rumah berfungsi ganda dapat diteliti dengan berbagai cara. Penelitian ini menggunakan metode: Deduktif Kualitatif “Fenomenologi" (Sudaryono, 2004).

Gambar 1. Diagram Metode Penelitian Deduktif Kualitatif "Fenomenologi” (Sudaryono, 2004)

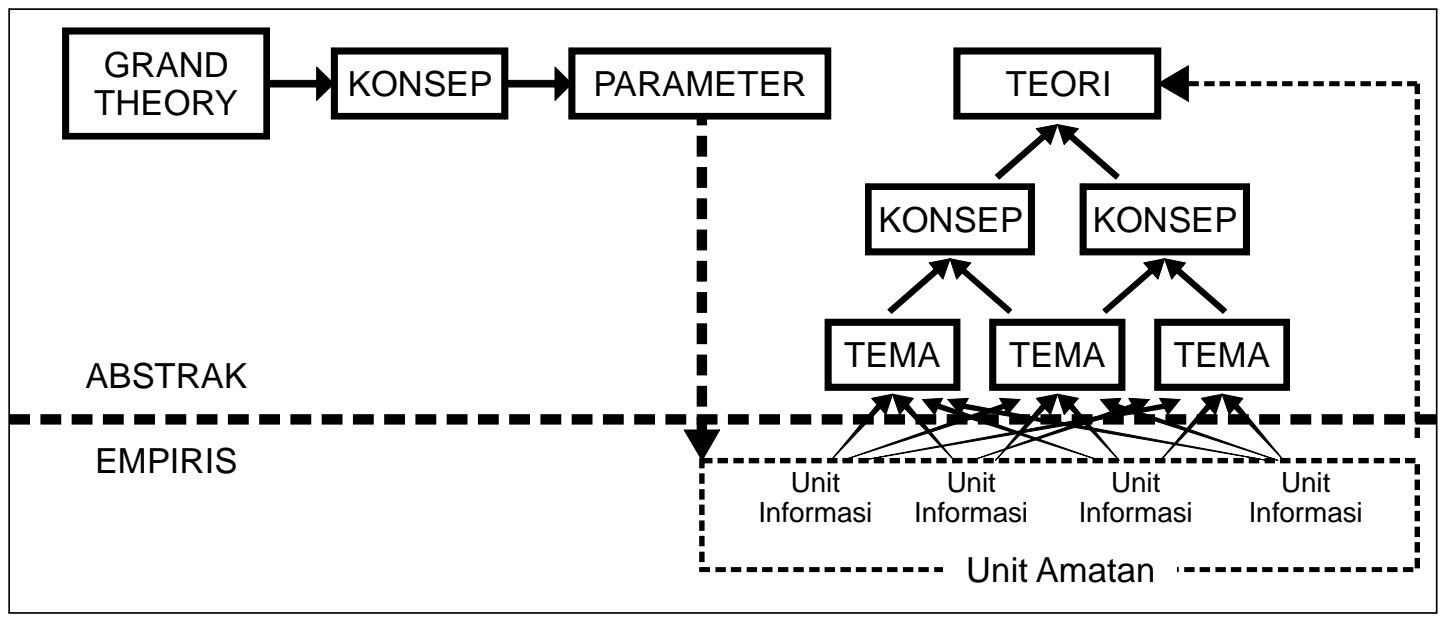


Alasannya adalah karena penelitian ini bertujuan untuk mendapatkan konsep teoritik dengan parameter-parameter dan konsep yang diturunkan dari grand teori untuk pengamatan di lapangan

Kasus penelitian adalah rumah tinggal yang telah berubah menjadi rumah berfungsi ganda dan rumah berfungsi ganda yang telah dikembangkan oleh pemiliknya. Karena jumlah populasi rumah berfungsi ganda tidak diketahui maka pemilihan sampel secara porpusive berdasarkan beberapa kriteria yang relevan dengan tujuan penelitan. Kriteria tersebut tidak mengikat sepenuhnya, melainkan dapat menyesuaikan situasi rumah berfungsi ganda.

Dengan demikian kasus rumah berfungsi ganda sebagai contoh obyek pengumpulan data dapat ditentukan. Responden yang diharapkan memberikan informasi adalah: pemilik rumah berfungsi ganda secara pribadi atau kelompok. Responden dipilih secara porpusive, dengan dasar pemilihan: a) mereka yang sehari-hari tinggal di rumah, b) mereka pemilik rumah yang mengelola tempat usaha

\section{DESKRIPSI DAERAH UMBULHARJO}

Dua dasa warsa yang lalu Umbulharjo merupakan daerah agraris yang sebagian besar penduduknya bercocok tanam. Seiring dengan pemekaran dan perkembangan kota Yogyakarta maka daerah ini kemudian berkembang menjadi kampung kota yang struktur masyarakatnya heterogen, baik status pekerjaan, tingkat penghasilan, pendidikan, maupun status sosialnya. Sebagian masyarakat daerah ini masih mempunyai gaya hidup pedesaan, yang masih mempertahankan pola kehidupan tradisional, seperti gotong royong, paguyuban, sifat kekeluargaan serta memiliki kesadaran hidup beragama yang cukup tinggi.

Daerah Umbulharjo mulai kelihatan berkembang setelah didirikannya beberapa kampus Perguruan Tinggi yang agak besar. Kebutuhan akan rumah makin tinggi, hal ini disebabkan karena selain penduduk asli yang berkembang, banyak juga pendatang baru yang membangun rumah tinggalnya di daerah ini. Pesatnya perkembangan daerah Umbulharjo menyebabkan daerah tersebut sekarang menjadi kampung kota, yang diwarnai oleh rumah tinggal yang berfungsi ganda. Rumah tinggal berfungsi ganda sebagian besar adalah rumah tinggal yang juga digunakan untuk usaha dalam rangka melayani kebutuhan fasilitas mahasiswa.

Penghasilan sebagian besar penduduk meningkat dari tahun 1990 sampai tahun 2003 (hasil wawancara, 2004). Salah satu faktor penyebab peningkatan penghasilan penduduk daerah Umbulharjo adalah banyaknya permintaan untuk fasilitas mahasiswa, terutama jasa pondokan. Masyarakat daerah Umbulharjo yang membuka usaha jasa pondokan, warung makan, toko, wartel dan rental komputer sebagian besar adalah PNS dan pensiunan. Tetapi ada juga sebagian penduduk yang penghasilan utamanya hanya dari usaha jasa tersebut di atas.

Jumlah rumah tinggal berfungsi ganda di daerah Umbulharjo cukup banyak, dan lokasinya tersebar di daerah penelitian. Bentuk rumah berfungsi ganda sangat bervariasi, dan masyarakatnya sangat heterogen. Rumah berfungsi ganda di daerah Utara (Kalurahan Warungboto dan Mujamuju) mempunyai mobilitas yang tinggi karena di satu sisi dekat dengan pusat pemerintahan kota dan terminal Bis, dan di sisi lain banyak terdapat kampus Perguruan Tinggi.

Berdasarkan observasi dilapangan maka terdapat 3 kategori rumah berfungsi ganda sesuai dengan jenis usaha utama yang dilakukan, yaitu:

a. Rumah Tinggal merangkap Pondokan.

b. Rumah tinggal merangkap Warung makan

c. Rumah tinggal merangkap Toko

\section{Fenomena Rumah Tinggal Berfungsi Ganda di Daerah Umbulharjo.}

Berdasarkan beberapa kriteria yang digunakan untuk memilih sample maka didapatkan 36 rumah tinggal berfungsi ganda. Kemudian dari ke 36 sample tersebut di atas direduksi menjadi 9 sampel sebagai studi kasus, berdasarkan kategori fungsi ruang yang digunakan untuk ruang usaha. Sembilan kasus tersebut di atas diambilkan dari ketiga kategori jenis usaha utama pada rumah berfungsi ganda yaitu: 
a. Rumah tinggal merangkap pondokan ada 3 kasus (Rp.2, Rp 7, Rp.9)

b. Rumah tinggal merangkap warung makan ada 3 kasus (Rwm 1, Rwm 3, Rwm. 6)

c. Rumah tinggal merangkap toko ada 3 kasus (Rt. 3, Rt. 6, Rt 9)

\section{Kategorisasi Pola-pola Perubahan Sistem Spasial Rumah Tinggal Berfungsi Ganda.}

Dari hasil penelitian terhadap kesembilan rumah kasus yang telah diuraikan di dalam 9 tabel, terungkap adanya fenomena perubahan sistem spasial pada rumah-rumah berfungsi ganda. Pada bagian ini dicermati perubahan-perubahan yang terjadi pada kesembilan rumah kasus sebagai titik tolak untuk menganalisis perubahan-perubahan keseluruhan rumah tinggal berfungsi ganda.

Dari analisa kesembilan rumah tinggal berfungsi ganda pada perubahan struktur spasial (organisasi ruang, hubungan ruang, hirarki ruang, orientasi, akses dan sirkulasi, teritori fisik) semuanya mengalami perubahan kecuali orientasi. Untuk perubahan nilai spasial, sebagian besar mengalami perubahan, ruang yang sebelumnya merupakan ruang untuk kehidupan keluarga menjadi ruang yang digunakan untuk komersiil, sesuai dengan pernyataan bahwa perubahan penggunaan ruang atau fungsi pada rumah tinggal itu karena adanya interaksi penghuni dengan rumahnya (Silas,J.dkk, 2000:297). Dan pola perubahan yang terjadi adalah nilai ekonomi, nilai fungsi dan nilai sosial.

Sedangkan proses perubahan berkaitan dengan tahap perubahan, laju perubahan dan arah perubahan. Proses perubahan berkaitan dengan kemampuan manusia berdasarkan tersedianya dana, sehingga dilakukan dengan laju secara gradual atau serentak. Pola tahap perubahan yang terjadi sebagian besar dimulai dari membuat tempat usaha atau membongkar dinding bagian luar dari rumah (kulit), baru kemudian melengkapi isinya. Perubahan ini dengan motivasi prioritas komersiil (tambahan ekonomi) dan keamanan. Sedangkan pola arah perubahan beragam, hal ini disebabkan karena tersedianya lahan dan dana.

\section{Analisa Kadar Pengaruh Perubahan Sistem Spasial Terhadap Rumah Lama.}

Dari analisis struktur spasial kesembilan kasus rumah tinggal berfungsi ganda tersebut dihasilkan bahwa sebagian besar kadar pengaruh perubahan struktur spasial terhadap rumah lama kecil. Hal ini disebabkan masih adanya keinginan untuk mempertahankan struktur spasial rumah lama (identitas rumah lama masih dominant).

\section{Arah Kecenderungan Perubahan Sistem Spasial pada Rumah Tinggal Berfungsi Ganda}

Berdasarkan analisis dari kesembilan sampel dapat diidentifikasikan arah kecenderungan perubahan sistem spasial rumah berfungsi ganda dilihat dari organisasi ruang, menunjukkan bahwa arah perubahan fungsi ruang cenderung ke alih fungsi, dan arah perubahan susunan ruang cenderung ke pusat dan liner.

Arah perubahan hirarki ruang cenderung pada perubahan hirarki rendah. Sementara itu arah perubahan orientasi cenderung tidak mengalami perubahan. Kemudian arah perubahan akses dan sirkulasi cenderung pada pola penyatu antara penghuni rumah dengan pemondok maupun pembeli. Sedangkan arah perubahan teritori fisik cenderung ke arah penambahan elemen, hal ini hampir sama dengan pernyataan Habraken (1982, h.14) bahwa perubahan elemen pembentuk ruang dalam suatu site dapat diindikasikan dengan menggunakan tiga dasar yaitu: penambahan (addition), pengurangan (eliminition) dan perpindahan (movement).

\section{Pengembangan (Komparasi) Kasus-kasus Perubahan Sistem Spasial Rumah Tinggal Berfungsi Ganda}

Berdasarkan analisis kesembilan sampel, maka dapat dilakukan pengembangan (komparasi) kasus-kasus perubahan sistem spasial rumah tinggal berfungsi ganda. Pengembangan kasuskasus perubahan ini ditinjau dari pola perubahan kategori struktur spasial dan proses perubahan yang dikaitkan dengan konteks kasus, motivasi dan kesesuaian 
karakter konteks yang disajikan dalam tabel di bawah ini:

Tabel 1 Perincian Perubahan Sistem Spasial Rumah Berfungsi Ganda Pada Konteks Kasus

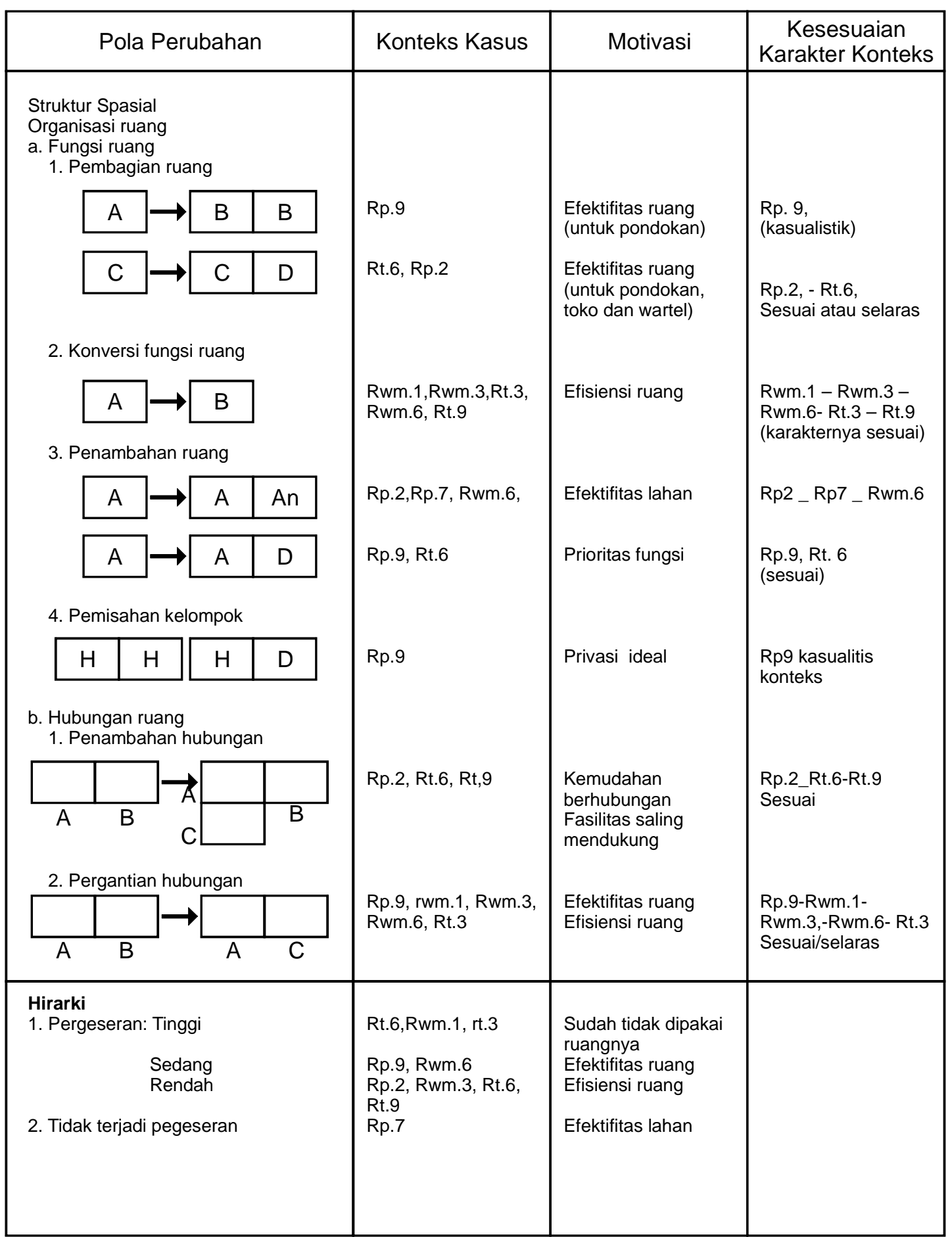


RUANG | VOL.2 | EDISI 2 | 2008

\begin{tabular}{|c|c|c|c|}
\hline Pola Perubahan & Konteks Kasus & Motivasi & $\begin{array}{c}\text { Kesesuaian } \\
\text { Karakter Konteks }\end{array}$ \\
\hline $\begin{array}{l}\text { Orientasi } \\
\text { 1. Konstan dikuti tempat } \\
\text { Usaha } \\
\begin{array}{l}\text { 2. Konstan tidak diikuti } \\
\text { tempat usaha }\end{array}\end{array}$ & $\begin{array}{l}\text { Rp.7, Rp.9, Rwm.1, } \\
\text { Rwm.6, Rwm9 Rt.3, } \\
\text { Rt.9 } \\
\text { Rp.2, Rt.6 }\end{array}$ & $\begin{array}{l}\text { Mempertahankan } \\
\text { rumah lama, stra } \\
\text { tegis, mudah dike } \\
\text { nal } \\
\text { Mempertahankan } \\
\text { rumah lama, sesuai } \\
\text { dengan kondisi } \\
\text { lahan }\end{array}$ & $\begin{array}{l}\text { Sesuai } \\
\text { Sesuai }\end{array}$ \\
\hline $\begin{array}{l}\text { Sirkulasi/akses } \\
\text { 1 Penambahan akses } \\
\text { 2.Penambahan sirkulasi } \\
\text { 3 Relokasi entry } \\
\text { 4. Perpindahan sirkulasi }\end{array}$ & $\begin{array}{l}\text { Rp.2, rwm1, Rwm6, } \\
\text { Rt.9 } \\
\text { Rp2, Rwm1 } \\
\text { Rt6, Rp,9, Rwm3, } \\
\text { Rwm6, Rt,3, Rt3, } \\
\text { Rt6, Rt9. } \\
\text { Rt.7, Rp9, Rwm3, } \\
\text { Rwm6, Rt,3, Rwm6, } \\
\text { Rt.6 }\end{array}$ & $\begin{array}{l}\text { Privasi tidak } \\
\text { terganggu } \\
\text { Kemudahan penca } \\
\text { paian, kebersamaan } \\
\text { Keamanan, } \\
\text { kemudahan } \\
\text { pencapaian } \\
\text { Karena susuanna } \\
\text { ruangnya berubah }\end{array}$ & Sesuai \\
\hline Teritori fisik & & & \\
\hline 1.Penambahan struktur & $\begin{array}{l}\text { Rp2, Rp.7, Rp.9, } \\
\text { Rwm6 }\end{array}$ & $\begin{array}{l}\text { Permanensi, } \\
\text { keserasian, } \\
\text { penampilan }\end{array}$ & Sesuai \\
\hline 2.Penambahan elemen semi fix & $\begin{array}{l}\text { Rp.9, Rwm3, Rm6, } \\
\text { Rt.3, Rt.6 }\end{array}$ & $\begin{array}{l}\text { Semi permanensi, } \\
\text { mudah dirubah }\end{array}$ & Sesuai \\
\hline 3. Renovasi & $\begin{array}{l}\text { Rwm1, Rwm3, Rt.3, } \\
\text { Rwm6, Rt.6, Rt.9 }\end{array}$ & Peningkatan kualitas & Sesuai \\
\hline
\end{tabular}

Tabel 2 Perincian Tahapan Perubahan Sistem Spasial Rumah Berfungsi Ganda Pada Konteks Kasus

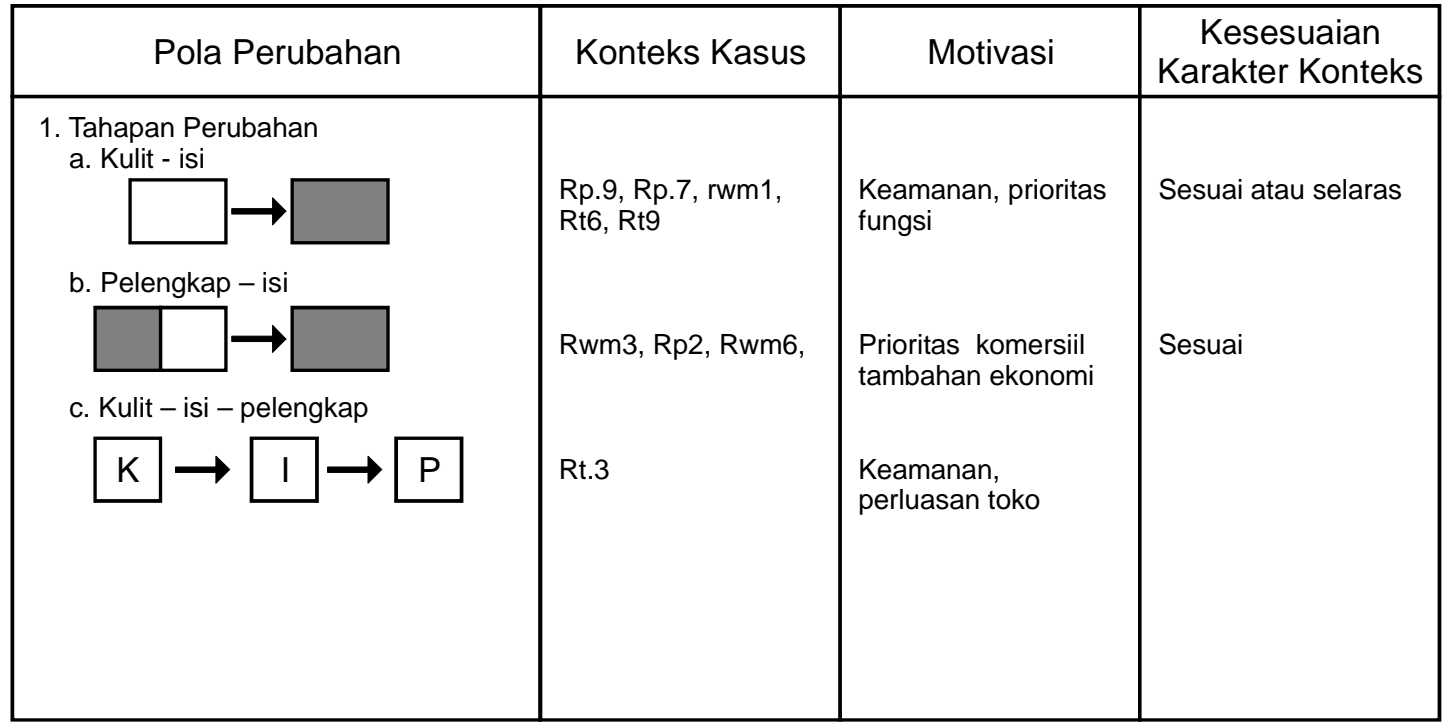




\begin{tabular}{|c|c|c|c|}
\hline Pola Perubahan & Konteks Kasus & Motivasi & $\begin{array}{c}\text { Kesesuaian } \\
\text { Karakter Konteks }\end{array}$ \\
\hline 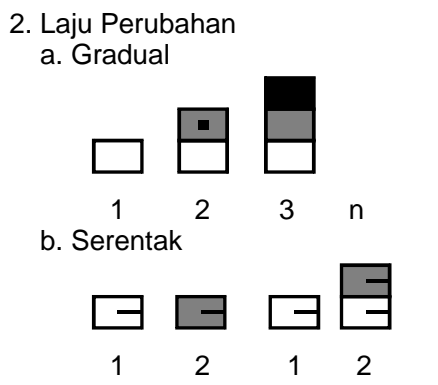 & $\begin{array}{l}\text { Rp.9, Rp.7, Rwm.1, } \\
\text { Rt. 6, Rt.9. } \\
\\
\text { Rwm.3, Rp.2, } \\
\text { Rwm.6, Rt.3 }\end{array}$ & $\begin{array}{l}\text { - Dana yang tersedia } \\
\text { - Pengembangan } \\
\text { usaha (kasus Rt.6) } \\
\text { - Dana yang tersedia } \\
\text { cukup } \\
\text { - Kebutuhan } \\
\text { mendesak }\end{array}$ & Sesuai \\
\hline $\begin{array}{l}\text { 3. Arah Perubahan } \\
\text { a. Ekspansi internal } \\
\text { b. Ekspansi eksternal horisontal } \\
\text { c. Ekspansi eksternal vertikal } \\
\text { d. Ekspansi eksternal } \\
\text { horizontal dan vertikal } \\
\mathrm{A} \rightarrow \frac{\mathrm{A}}{\mathrm{A}} \\
\mathrm{A}\end{array}$ & $\begin{array}{l}\text { Rp.7, Rp.9, Rwm1, } \\
\text { Rwm3, Rt3, Rt9. } \\
\text { Rp.7, Rwm.6, Rt.6 } \\
\text { Rt.3 } \\
\text { Rp.2, Rp.9. }\end{array}$ & $\begin{array}{l}\text { Efisiensi dan } \\
\text { efektifias uang } \\
\text { Efektifitas lahan } \\
\text { Efektifitas Ruang }\end{array}$ & $\begin{array}{l}\text { Sesuai } \\
\text { Ketiga konteks } \\
\text { sesuai }\end{array}$ \\
\hline
\end{tabular}

\section{PENUTUP}

Berdasarkan kategorisasi unit-unit kasus, kadar pengaruh perubahan terhadap rumah lama, arah kecenderungan perubahan dan komparasi kasus-kasus rumah tinggal berfungsi ganda diperoleh temuan-temuan sebagai berikut:

\section{Bentuk Perubahan Sistem Spasial pada} Rumah Tinggal Berfungsi Ganda

\section{Struktur Spasial:}

\section{a. Organisasi ruang}

Organisasi Ruang., terjadi perubahan beragam dengan arah meningkatkan efisiensi ruang untuk memperoleh keuntungan ekonomis. Bentuk perubahan alih fungsi paling banyak adalah toko dan warung makan. Sedangkan yang menambah ruang untuk ruang usaha yang paling besar adalah usaha pondokan. Perubahan fungsi ruang dengan pola : pembagian ruang, konversi ruang, penambahan ruang, dan pemisahan ruang.

Dalam hubungan ruang antara rumah induk dan pondokan terjadi penguatan yang bertujuan untuk mengontrol keberadaan pondokan. Sedang pada usaha warung makan, hubungan ruang cenderung berubah karena adanya perbedaan fungsi yang dominan antara warung (publik) dengan tempat tinggal (privat). Pola perubahannya berupa penambahan hubungan dan pergantian hubungan

\section{b. Hirarki ruang}

Secara hierarkhi ruang, maka pada usaha pemondokan terjadi pergeseran area privat ke arah semi public (pergeseran hirarki tinggi). Sedang pada usaha warung makan dan toko (pergeseran hirarki sedang dan rendah), perubahan di atas kurang berarti karena umumnya ruang usaha menempati 
halaman depan atau teras yang sudah bersifat semi publik atau publik.

\section{c. Orientasi ruang}

Dalam orientasi umumnya tidak terjadi perubahan karena adanya keinginan untuk mempertahankan rumah lama dan menyesuaikan dengan ruang usahanya. Kecuali pada kasus-kasus tertentu yang disebabkan karena kondisi site yang spesifik, misal adanya jalan samping /belakang. Pola perubahnnya terdapat dua pola yaitu "konstan diikuti tempat usaha" dan "konstan tidak diikuti tempat usaha".

\section{d. Sirkulasi/akses}

Peningkatan kepadatan arus sirkulasi paling besar adalah pada kasus warung makan dan toko sedangkan pada rumah usaha pemondokan hanya sebagian saja. Maka pola perubahan yang terjadi adalah: penambahan akses, penambahan sirkulasi, relokasi entry, dan perpindahan sirkulasi.

\section{e. Teritori fisik}

Pada pembatas ruang (teritori), terjadi perubahan yang bersifat permanen dan semi permanen. Perubahan vertikal dan permanen lebih banyak terjadi pada rumah pondokan, sedang perubahan ke arah horisontal dan kurang permanent banyak terjadi pada usaha warung dan toko.

Pola perubahan yang terjadi adalah : penambahan struktur, penambahan elemen semi fix dan renovasi

\section{Nilai spasial}

Perubahan nilai spasial sebagian besar karena faktor ekonomi yang diikuti dengan faktor sosial, dengan memanfaatkan kesempatan adanya kegiatan baru yaitu kegiatan pendidikan perguruan tinggi.

\section{Proses Perubahan}

Secara keseluruhan tahap perubahan cenderung dimulai dari pelengkap (ruang usaha) baru isi (detailnya), tahap perubahan ini bermaksud untuk keamanan dan prioritas fungsi usaha. Sementara itu secara keseluruhan laju perubahan cenderung meningkat secara bertahap (gradual) dengan motivasi ketersedianya dana dan pengembangan usaha. Dan diikuti dengan laju perubahan secara cepat (berpola serentak), dengan motivasi kebutuhan yang mendesak dan tersedianya dana. Sedangkan arah perubahan cenderung pada konsolidasi internal horisontal, dan diikuti dengan ekspansi eksternal horisontal dan vertikal, hal ini dengan maksud untuk mengefektifkan lahan atau ruang yang kosong/tidak terpakai.

4. Motivasi masyarakat untuk melakukan perubahan

Motivasi perubahan sistem spasial dari ketiga jenis kegiatan rumah berfungsi ganda ini hampir sama yaitu disebabkan oleh beberapa faktor yang bisa dibedakan dalam dua hal:

a.Pengaruh dari dalam (endogen) yaitu berasal dari kebutuhan penghuni rumah untuk peningkatan kebutuhan hidup.

b.Pengaruh dari luar (eksogen) yaitu berasal dari lingkungan luar penghuni rumah, antara lain kegiatan pendidikan dan berdirinya beberapa kampus, sehingga banyak permintaan mahasiswa untuk menuhi kebutuhannya selama belajar.

\section{DAFTAR PUSTAKA}

Bintarto, R.,1984. Interaksi Desa dan Kota, JAKARTA: Ghalia Indonesia.

Ching, DK., 1987. Interior Design Illustrated, NEW YORK: Van Nostrand Reinhold Company.

Ching, FDK., Penyadur Hanoto Adjie, 1996. Arsitektur: Bentuk-Ruang \& Susunannya, JAKARTA: Penerbit Erlangga.

Corbin, J dan Strauss, A. Penyadur Ghony, D. 1997. Dasar-Dasar Penelitian Kualitatif. SURABAYA: PT. Bina IImu .

Dermawati, 1994. Perubahan Spasial Pada Rumah Tinggal Di Kampung Sosrowijayan Wetan Yogyakarta. YOGYAKARTA: Tesis S2 Jurusan Teknik Arsitektur UGM . 
Habraken, NJ.,1982. Transformation Of The Site, MASSACHUSETTS: MIT Press .

Kennedy, RW. , 1963. The House and The Art of its Design, NEW YORK: Reinhold Publishing Corporation.

Koentjaraningrat, 1984. Kebudayaan Jawa, JAKARTA: Balai Pustaka.

Lang, Jon, 1987. Creating Architectural Theory. The Role of the Behavioral Sciences in Environmental Design, NEW YORK: Van Nostrand Reinhold Company.

Lynch Kevin, 1992. The Image of City, LONDON: The MIT Press.

Muhadjir, 1993. Metodologi Penelitian Kualitatif, YOGYAKARTA: Rake Sarasin PO. Box 83.

Papageorgiou, A., 1971. Continuity and Change, NEW YORK: Praeger Publisher.

Purwanto AN, 2003. Studi Perubahan Spasial Rumah Tinggal Menjadi Rumah Pondokan Mahasiswa Di Yogyakarta. YOGYAKARTA: Tesis S2 Jurusan Arsitektur UGM .

Rapoport Amos, 1969. House Form and Culture, LONDON: Prentice-Hall INC.

Rapoport Amos, 1983. The Meaning of the Built Environment. A Nonverbal Communication Approach, LONDON: Sage Publications Ltd.

Sumarjo, 1998. Kajian Perubahan bentuk Arsitektur Rumah Pondokan Di Daerah Pinggiran Kota. YOGYAKARTA: Tesis S2 Jurusan Arsitektur UGM . 
$\underset{\text { ISSN 1978-0702 }}{\text { LINTAS }}$ 